\title{
Indian Poetry in Slovenian Cultural Space
}

\author{
Andreja Radetič \\ School Centre Krško-Sevnica, Slovenia \\ Email: andreja.radetic@gmail.com
}

\begin{abstract}
The article attempts to analyse how known Indian poetry is in Slovenian cultural space, which authors have been translated and what research has been done into it. The article finds that Indian poetry is despite differences between Slovenian and Indian cultural spaces relatively well known. The most widely read poet is Rabindranath Tagore, who strongly influenced Slovenian modernist poet Srečko Kosovel. Publications of Indian poetry are mostly limited to anthologies.
\end{abstract}

Keywords- Indian poetry, Rabindranath Tagore, Slovenian cultural space, Srečko Kosovel.

\section{INTRODUCTION}

One might believe that Indian poetry in Slovenian cultural space $^{1}$ is relatively unknown, especially to general public. However, this is not true. Amongst academics, critics and other scholars Indian poetry has been studied for at least a century now, mostly due to the most known Indian poet in Slovenia Rabindranath Tagore.

\section{RABINDRANATH TAGORE}

Tagore's popularity started growing right before WW I. There were at least two reasons for his growing popularity, the first one being the fact that Tagore received a Nobel Prize for Literature in 1913 as the first non-European. However, the bare fact of him receiving the award is not the main reason for initial interest in him. What is more important is that the Swedish Academy denied Peter Rosegger (1843-1918), who was much disliked among Slovenian public due to his antiSlovenian activities. Academy's decision was to blame that the news rapidly spread and that Tagore was widely read. There were numerous articles in Slovene newspapers and magazines about himself and his poetry; almost 400 only while he was still alive. In the period of seven years from 1917 to 1924 five of his poem collections were translated (see below). The most extensive study of the time entitled Lanska tekmeca za Nobelovo nagrado (Last year competitors for Nobel Prize) was written by Janko Lokar and published as a foreword to Stray Birds in 1913.

\footnotetext{
${ }^{1}$ In this article the term Slovenian cultural space is used to refer to all cultural activities in Slovenia.
}

Not until a few years later Tagore's name stopped appearing in connection to Rosegger. And not until then Tagore was seen in his true magnificence as a poet of love, prophet and Eastern wise man, cherished by entire Europe (in 1920s).

\section{TAGORE AND KOSOVEL}

Another reason for his popularity was the growing interest of Slovenian poets in Orientalism. Tagore had a major influence on Slovenian poet Srečko Kosovel (19041926). Tagore's influence on Slovenian modernist poet was also the reason why the first truly deep study of Bengali's work was published, but not until much later. Ana Jelnikar's study Svetova Rabindranatha Tagoreja in Srečka Kosovela was published by Oxford University Press in 2016; English translation of the study (Universalist Hopes in India and Europe: the Worlds of Rabindranath Tagore and Srečko Kosovel) by Barbara Siegel Carlson was published in New Delhi in 2016.

Ana Jelnikar claims that Tagore holds a central position in Kosovel's canon since Tagore is most often mentioned person in Kosovel's poems. Kosovel wrote a poem $A$ Golden Boat and was planning to use this title for his poem collection. It is an obvious reference to Tagore's poem with the same title. Furthermore, Jelnikar stresses the motif similarity between both poems. Although Kosovel constantly wrote about death and suffering, he still expressed his hope in a different and rebellious "new man" who will face life with pride. Similarly, Tagore wrote about life full of pain and suffering on one hand and joy on the other. The image of Kosovel's new man reaching harmony is frequently linked to Tagore's image: In green India in the midst of silent over the blue waters sheltered trees / Tagore finds home (translated by Boris Gregorič).

They were both anti imperialists. They conditioned mental rebirth and resurrection of a »new man « with the ruin of imperialism and capitalism. Despite the use of different imagery, Kosovel's Ekstaza smrti (The Extasy of Death) and Tagore's Sunset of the Century (Sončni zahod stoletja) both criticize destructive capitalism. Importantly enough, they were both looking for a pacifist solution. Jelnikar saw a reason why young Kosovel found a role model in Tagore in their similar mental-historical background. Both Tagore and Kosovel belonged to two 
nations and spoke languages which were exposed to extensive repressions. While Tagore lived under British rule and repression, Kosovel was exposed to Italian oppressions and was a witness to fascist rise. Tagore looked for peaceful coexistence of different cultures and similarly Kosovel saw the solution for the Slovenian nation in international connections. Since both issues are just as relevant today as they were a century ago, Tagore's standpoint is just as relevant as it was a century ago.

There was also some research done on how Tagore influenced other Slovenian poets, but no significant connection has been found yet. Urška Kobe (2012) found a connection to Anton Aškerc (1856-1912), but Aškerc was only interested in Tagore as a theologist. Aškerc was unable to identify with Tagore on any deeper level, mostly due to a cultural-religious gap.

There have been numerous attempts to popularize Tagore's poetry (and Indian poetry in general), but it is important to keep in mind a relatively big cultural gap between the Bengali writer (and other Indian poets) and the Slovenian (average) reader. Interpretations and attempts of explanations of Indian poetry mostly fall down to term explanations; i. e. stressing the importance of Jibandebata, which is explained as personalized deity of poet's inner life as an attempt to overcome the Romantic dualism.

\section{ANTHOLOGIES, OTHER PUBLICATIONS AND EVENTS}

The majority of Tagore's poetry in early 20th century was translated from English by Alojz Gradnik. Rastoči mesec ${ }^{2}$ was first published in 1921 by Omladina in Ljubljana. It was followed by Ptice selivke ${ }^{3}$ (I. Kleinmayr \& F. Bamberg) later in the same year, $\operatorname{Vrtnar}^{4}$ (Zvezna tiskarna) and Žetev ${ }^{5}$ (L. Schwentner) in 1922, Gitandžali ${ }^{6}$ (Učiteljska tiskarna) in 1924.

Through the years two more poetry collections have been added to this list: Darovanjke 7 (Mladinska knjiga) in 2011 (translated by Janko Moder) and Lipika (Mohorjeva družba) in 1988 (translated by Miriam Drev).

\section{ANTHOLOGIES, OTHER PUBLICATIONS AND EVENTS}

Most publications of Indian poetry are limited to anthologies, which attempt to include the selection of most representative poems of chosen authors.

\footnotetext{
2 The Crescent Moon

${ }^{3}$ Stray Birds

${ }^{4}$ The Gardener

${ }^{5}$ Fruit Gathering

${ }^{6}$ Gitanjali

${ }^{7}$ Song Offerings
}

In 1973 a selection of Sanskrit poetry was published by Mladinska knjiga entitled Kot bilke, kot iskre. Unlike Tagore's collections these poems were translated by Vlasta Pacheiner-Klander directly from Sanskrit. The collection includes a selection of poems from The Vedas, Upanishads, Kalidasa, Bhartrihari, Bilhana, Jayadeva.

As mentioned below, Milan Štante published an anthology of modern Indian poetry in 1978. In 1992 another collection of modern Indian lyrical poetry entitled Eden je ta svet was published by Milan Štante, who also wrote a foreword. There he attempts to explain the cultural circumstances in modern India, which influence styles and other poetic characteristics in modern Indian poetry.

One of a few exceptions is a translation of Sukumar Ray's collection. His poem collection Brezvezne rime ${ }^{8}$ was published in 2017 by KUD Sodobnost International. Milan Dekleva's translation was well-received by the critics and youth.

The 30th Inetrnational Vilenica Festival in $2015^{9}$ paid homage to the literature of India, titled Kavita. The festival hosted three Indian poets: K. Satchidanandan, Haraprasad Das, and Sitanashu Yashaschandra. The anthology of contemporary Indian poetry Vilenica 2015 features 31 male and female authors.

The festival unveiled the 10th volume of the Vilenica Anthologies titled Kavita. The anthology of contemporary Indian poetry. It features 31 male and female authors. The contributing authors are Sirpi Balasubramaniam, Mangalesh Dabral, Haraprasad Das, Ranajit Das, Hemant Divate, Gnanakoothan, Sankha Ghosh, Adil Jussawalla, Chandrashekhara Kambar, Pravasini Mahakud, Jayanta Mahapatra, Prathibha Nandakumar, Kunwar Narain, Jameela Nishat, Jayant Parmar, Surjit Patar, Nilmani Phookan, Savithri Rajeevan, Ramakanta Rath, Padma Sachdev, K. Satchidanandan, Nabaneeta Dev Sen, Malika Amar Sheikh, Kedarnath Singh, Yumlembam Ibomcha Singh, H. S. Shivaprakash, K. Sivareddy, Arundhathi Subramaniam, Vishwanath Prasad Tiwari, Kamal Vora, and Sitanshu Yashaschandra. The author responsible for the initial selection of contributing authors was K. Satchidanandan, who tried to secure a place in the anthology for the best poets, writing in the largest number of Indian languages possible. He focused particularly on quality, relevance, contemporaneity, and on a healthy balance between male and female poets.

\footnotetext{
${ }^{8}$ Abol Tabol

${ }^{9}$ More about Vilenica Festival at https://vilenica.si/.
} 


\section{INDIAN POETRY IN SLOVENIAN} EDUCATIONAL SYSTEM

At Slovenian primary schools Indian literature is not taught. At grammar schools students have been reading old Oriental poetry since 1962. Shortly after WW II Oriental literature ${ }^{10}$ was included into the university programme of Comparative literature. The first lecturer was Anton Ocvirk, who had a vital role in introducing Oriental literature to Slovenian general and academic public. He encouraged two of his students into specialization in Indian culture. One of them, Vlasta Pacheiner-Klander wrote a study which dealt with old Indian poetics (Staroindijska poetika ${ }^{11}$ ). The study introduces main periods of old Indian poetics and its directions.

Milan Štante, another Ocvirk's student, who was granted a two-year study in India, was fascinated by Indian poetry, which he introduces in articles, translations and literary events for general public. In 1978 he published an anthology with his translations of Indian poetry Košara človekovega srca with a very extensive foreword.

\section{CONCLUSION}

Taking into account the scope of Indian poetry, the number of translations into Slovenian is still relatively scarce. There is a cultural-religious gap to blame, but also the lack of translators, who can translate directly from Indian languages. However, the interest in Indian poetry is vivid, therefore more translations are expected in the future.

\section{REFERENCES}

[1] Pacheiner-Klander, V. (2008), »Orientalske literature v programu profesorja Ocvirka za študij svetovne književnosti, « in Primerjalna književnost v 20. stoletju in Anton Ocvirk, D. Dolinar and M. Juvan, Eds. Ljubljana: Studia Litteraria, pp. 123-134.

[2] Jelnikar, A. (2016). Universalist hopes in India and Europe: the worlds of Rabindranath Tagore and Srečko Kosovel. New Delhi: Oxford University Press.

[3] Kobe, U. (2012), Vpliv Ved na pesmi Antona Aškerca in Rabindranatha Tagoreja: diplomsko delo, unpublished.

[4] Pacheiner-Klander, V. (1973). Kot bilke, kot iskre: izbor sanskrtske lirike. Ljubljana: Mladinska knjiga.
[5] Štante, M. (1992). Eden je ta svet. Ljubljana: Karantanija.

[6] Kavita, Antologija sodobne indijske poezije (2015), K. Satchidanandan in Evald Flisar, Eds. Ljubljana: Društvo slovenskih pisateljev.

[7] Festival Vilenica. Retreived from https://vilenica.si/

\footnotetext{
${ }^{10}$ The term Oriental literature means Indian, Arabic, Turkish and other literatures from Middle East and other parts of Asia.

${ }^{11}$ Pacheiner.Klander, V. (1982). Staroindijska poetika. Ljubljana: Državna založba Slovenije.
} 